\title{
Pengaruh Penambahan Pengawet dan Uji Aktivitas Antibakteri Escherichia coli pada Sediaan Gel Lidah Buaya
}

\author{
The Effect of Preservative Addition and Antibacterial Activity Test of \\ Escherichia coli on Aloe vera Gel Preparation
}

\author{
Sukma Budi Ariyani \\ Baristand Industri Pontianak \\ Kementerian Perindustrian \\ Pontianak, Indonesia \\ sukma_ariyani@kemenperin.go.id
}

\author{
Yani Kartika Pertiwi \\ Baristand Industri Pontianak \\ Kementerian Perindustrian \\ Pontianak, Indonesia
}

\author{
Asmawit \\ Baristand Industri Pontianak \\ Kementerian Perindustrian \\ Pontianak, Indonesia
}

\begin{abstract}
Abstrak-- Gel lidah buaya mempunyai kandungan zat yang dapat digunakan untuk industri farmasi maupun kosmetik. Untuk mendapatkan suatu produk farmasi atau kosmetik dari lidah buaya diperlukan bahan baku sediaan gel lidah buaya yang berkualitas baik. Penelitian ini bertujuan untuk mengetahui pengaruh penambahan pengawet pada sediaan gel lidah buaya dan mengetahui daya hambat terhadap bakteri Escherichia coli pada sediaan gel lidah buaya. Metode penelitian yang dilakukan meliputi pembuatan sediaan gel lidah buaya dan penambahan pengawet, pengamatan fisik gel dan pengujian Angka Lempeng Total (ALT) serta pengujian daya hambat bakteri Escherichia coli. Variabel berubah yang digunakan adalah jenis pengawet (Potassium Sorbat dan Sodium Benzoat), konsentrasi pengawet $(0,05 \%, 0,10 \%$ dan $0,15 \%$ ), suhu penyimpanan (suhu kamar dan kulkas) dan waktu penyimpanan (7 hari dan 14 hari). Hasil yang diperoleh adalah penggunaan pengawet Sodium Benzoat $0,10 \%$ memberikan hasil sediaan gel lidah buaya yang terbaik dengan lama penyimpanan 14 hari. Jus dan gel lidah buaya memiliki aktivitas antibakteri Escherichia coli dengan diameter zona hambat masing-masing rata-rata 0,85 dan $0,6 \mathrm{~cm}$. Hal ini menunjukkan jus dan gel lidah buaya memiliki aktivitas antibakteri Escherichia coli dengan kriteria sedang.
\end{abstract}

Kata Kunci-- Escherichia coli, gel lidah buaya, pengawet

\begin{abstract}
Aloe vera gel contains good substances that can be used for both pharmaceutical and cosmetic industries. In order to obtain pharmaceutical product from Aloe vera gel, raw material with good quality is needed. This study aimed to explore the effect of preservatives addition and to determine the inhibitory power of Escherichia coli on aloe vera gel preparation. The methods was including aloe vera gel preparation, preservative addition, physical observation, Total Plate Count (ALT) test, and inhibitory testing of Escherichia coli bacteria. The variables were preservatives type (Potassium Sorbat and Sodium Benzoate), preservative concentrations $(0.05 \%, 0.10 \%$ and $0.15 \%)$, storage temperature (room temperature and refrigerator) and storage time (7 days and 14 days). The result showed that usage of $0.10 \%$ Sodium Benzoat with 14 days storage time gave best result of aloe vera gel preparation. Aloe vera juice and gel had antibacterial activity of
\end{abstract}

Escherichia coli with inhibitory zone diameter each average 0.85 and $0.6 \mathrm{~cm}$. This shows that aloe vera juice and gel had antibacterial activity of Escherichia coli with moderate criteria.

Keywords: aloe vera gel, Escherichia coli, preservative

\section{PENDAHULUAN}

Lidah buaya merupakan salah satu tanaman yang memiliki beberapa keuntungan, diantaranya adalah sebagai bahan yang berguna untuk regenerasi sel kulit, antioksidan, adstringen dan antiseptic ${ }^{[1]}$. Keistimewaan lidah buaya ini terletak pada gelnya yang dapat membuat kulit tidak cepat kering dan selalu kelihatan lembab. Keadaan tersebut disebabkan sifat gel lidah buaya yang mampu meresap ke dalam kulit, sehingga dapat menahan kehilangan cairan yang terlampau banyak dari dalam kulit. Kandungan saponin yang terdapat dalam gel lidah buaya dapat membersihkan kotoran dari kulit, melembutkan, melembabkan dan menambah kehalusan kulit ${ }^{[2]}$. Kekayaan akan kandungan bahan yang didapat berfungsi sebagai bahan kosmetik, obat dan pelengkap gizi menjadikan lidah buaya sebagai tanaman ajaib, karena tidak ada lagi tanaman lain yang mengandung bahan yang menguntungkan bagi kesehatan selengkap yang dimiliki tanaman tersebut.

Lidah buaya (Aloe vera var. barbadensis) menjadi komoditas unggulan Provinsi Kalimantan Barat, khususnya Kota Pontianak. Komoditi lidah buaya merupakan produk unggulan yang hingga saat ini dibudidayakan di wilayah Kalimantan Barat dan menjadi komoditi unggulan Kota Pontianak yang memiliki keunggulan komparatif, yatu dapat tumbuh sangat baik pada lahan gambut jika dibandingkan dengan lahan lainnya ${ }^{[3]}$. Potensi yang dimiliki Provinsi Kalimantan Barat, khususnya Kota Pontianak dapat menjadikan sektor pertanian sebagai salah satu pilar pembangunan daerah di masa mendatang. 
Tanaman lidah buaya di Kalimantan Barat secara komersial mulai diusahakan sejak tahun 1995, diantaranya di Kota Pontianak (Siantan) dan Kabupaten Pontianak (Rasau Jaya). Awal perkembangannya, tanaman ini hanya diusahakan dalam skala kecil, namun, seiring tingginya permintaan hasil panen, tingginya produksi serta prospek pasar yang cukup baik pada saat itu mendorong pengembangan usaha tani lidah buaya dalam skala besar. Dalam perkembangan selanjutnya, pengusahaan tanaman lidah buaya sejak tahun 2005-2009 mulai mengalami penurunan dikarenakan keterbatasan sumber daya dan risiko jaminan pasar ${ }^{[4]}$. Perlu strategi khusus untuk mengembangkan kembali tanaman lidah buaya tersebut, mengingat bahwa begitu banyaknya manfaat yang terkandung dalam tanaman lidah buaya. berikut:

Taksonomi lidah buaya (Aloe vera L.) adalah sebagai

$\begin{array}{ll}\text { Kerajaan } & \text { : Plantae } \\ \text { Divisi } & \text { : Spermatophyta } \\ \text { Kelas } & \text { : Monocotyledoneae } \\ \text { Bangsa } & \text { : Liliflorae } \\ \text { Suku } & \text { : Liliaceae } \\ \text { Marga } & \text { : Aloe } \\ \text { Jenis } & : \text { Aloe barbadensis Miller }\end{array}$

Gel diperoleh dengan membelah batang lidah buaya. Gel ini mengandung zat anti bakteri dan anti jamur yang dapat menstimulasi fibroblast yaitu sel-sel kulit yang berfungsi menyembuhkan luka. Selain kedua zat tersebut, jeli lidah buaya juga mengandung salisilat, zat peredam sakit dan anti bengkak seperti yang terdapat dalam aspirin ${ }^{[6]}$.

Untuk memaksimalkan pemanfaatan lidah buaya, maka dibuatlah bahan baku sediaan gel lidah buaya yang berkualitas yang bisa digunakan untuk industri farmasi dan kecantikan. Dalam penelitian ini akan ditambahkan pengawet pada sediaan gel lidah buaya dan dilihat pengaruhnya terhadap kestabilan fisiknya pada masa simpan yang berbeda. Selain itu hasil jus dan sediaan gel lidah buaya akan diuji daya hambatnya terhadap bakteri Escherichia coli dengan pengukuran diameter zona bening yang terbentuk.

Davis dan Stout (1971) menyatakan klasifikasi respon hambatan mikroba seperti pada Tabel $1^{[7]}$.

Tabel 1. Klasifikasi Respon Hambatan Mikroba

\begin{tabular}{cc}
\hline $\begin{array}{c}\text { Tabel 1. Klasifikasi Respon Hambatan Mikroba } \\
(\mathrm{mm})\end{array}$ & $\begin{array}{c}\text { Respon hambatan } \\
\text { pertumbuhan }\end{array}$ \\
\hline$>20$ & Sangat kuat \\
\hline $10-20$ & Kuat \\
\hline $5-10$ & Sedang \\
\hline$<5$ & Lemah \\
\hline
\end{tabular}

\section{BAHAN DAN METODE}

Bahan yang digunakan adalah lidah buaya barbadensis dari Aloe Vera Center Kota Pontianak, potassium sorbat dan sodium benzoate dari toko bahan kimia di Pontianak.

Alat yang digunakan diantaranya blender, baskom, pisau, botol kaca sampel $250 \mathrm{ml}$, botol sampel $100 \mathrm{ml}$, corong, kain saring, digital refraktometer merek ATAGO dengan rentang pengukuran brix $0,0-53,0 \%$ dan rotary vacuum evaporator merek BUCHI kapasitas $500 \mathrm{ml}$.

Penelitian ini dilaksanakan di Laboratorium Proses dan Laboratorium Mikrobiologi Baristand Industri Pontianak, meliputi beberapa tahap yakni :

\section{A. Pembuatan Sediaan Gel Lidah Buaya dan Penambahan Pengawet}

Lidah buaya dikupas, dicuci, diblender, disaring dengan kain saring dan diambil jus lidah buayanya. Selanjutnya diukur brix dengan alat digital refraktometer. Jus lidah buaya hasil blender tersebut sebanyak 500 gram gel dievaporasi menggunakan rotary vacuum evaporator hingga memperoleh gel dengan brix yang kita inginkan yakni 4-5,5. Gel lidah buaya yang diperoleh ditambah pengawet berupa potassium sorbat dan sodium benzoat sebanyak 3 (tiga) variabel yaitu $0,05 \%, 0,1 \%$ dan $0,15 \%$. Pengamatan dilakukan terhadap penampakan fisik dan cemaran bakterinya (Angka Lempeng Total). Jus lidah buaya dan gel lidah buaya yang telah ditambah pengawet yang terbaik diuji daya hambatnya terhadap bakteri Escherichia coli.

\section{B. $\quad$ Uji Angka Lempeng Total Sediaan Gel Lidah Buaya}

Metode pengujian merujuk kepada ISO/TS 4833:2003. Cara ujinya yakni gel lidah buaya ditimbang 25 gram, dimasukkan ke dalam erlenmeyer yang telah berisi 225 ml larutan pengencer hingga diperoleh pengenceran 1:10. Campuran dikocok beberapa kali hingga homogen. Pengenceran dilakukan sampai tingkat pengenceran tertentu sesuai keperluan. $1 \mathrm{ml}$ dari pengenceran 101 - 105 diambil dan dituangkan ke dalam cawan petri steril secara duplo. Kemudian ke dalam setiap cawan petri dituangkan sebanyak 12 - $15 \mathrm{ml}$ media PCA. Cawan petri digoyangkan hingga tercampur rata. Campuran dalam cawan petri dibiarkan hingga membeku. Cawan petri dengan posisi terbalik dimasukkan ke dalam lemari pengeram dan diinkubasi pada suhu 30oC selama 72 jam. Pertumbuhan koloni pada setiap cawan petri dicatat setelah 48 jam. Angka lempeng total dalam 1 gram contoh dihitung dengan mengalikan jumlah rata-rata koloni pada cawan petri dengan faktor pengenceran yang digunakan.

\section{Uji Daya Hambat Escherichia coli dengan Metode Kertas Cakram}

Pengujian aktivitas antibakteri dilakukan dengan metode Kirby-Bauer atau Paper disk, yaitu dengan mengamati dan mengukur zona hambat yang terbentuk.

Cakram dicelupkan ke dalam sampel (gel lidah buaya) sampai merata di seluruh permukaan cakram. Media nutrient agar yang telah disterilkan dituangkan ke dalam petridish. Media nutrient agar yang telah dingin dan memadat selanjutnya di tanami bakteri. Bakteri sebelumnya telah dibiakkan terlebih dahulu. Bakteri yang ditanam, diratakan hingga seluruh permukaan nutrient agar menggunakan 
spreader. Kemudian cakram tersebut diletakkan dalam media nutrient agar yang telah ditanami bakteri. Langkah selanjutnya dilakukan dengan inkubasi selama 24 jam. Aktifitas antibakteri ditunjukkan oleh luas diameter zona bening yang terbentuk.

\section{HASIL DAN PEMBAHASAN}

\section{A. Pengamatan Gel Lidah Buaya Setelah Ditambah Pengawet}

Gel lidah buaya yang diperoleh, ditambah dengan pengawet Potassium Sorbat 0,05\% (P0,05), 0,10\% (P0,1) dan $0,15 \%(\mathrm{P} 0,15)$. Gel lidah buaya dibuat sebanyak dua perlakuan yakni didiamkan dalam suhu kamar dan dimasukkan ke dalam kulkas, dengan lama penyimpanan selama 7 hari. Hasil penampakan fisik gel dapat dilihat pada Tabel 2. Dilihat dari Tabel 2, menunjukkan hasil bahwa gel lidah buaya yang dimasukkan ke dalam kulkas lebih tahan lama dibandingkan dengan gel lidah buaya yang disimpan pada suhu kamar. Suhu penyimpanan gel lidah buaya mempengaruhi warna dan bau gel lidah buaya.

Penyimpanan pada suhu ruang menyebabkan penurunan mutu fisik dan nilai gizi yang lebih cepat diikuti dengan proses pembusukan dibandingkan suhu rendah. Penyimpanan pada suhu rendah dapat menghambat kerusakan, antara lain kerusakan fisiologis, kerusakan enzimatis maupun kerusakan mikrobiologis. Hasil penelitian terdahulu yakni organoleptik (warna, aroma, tekstur) tomat yang dilapisi dengan konsentrasi perlakuan gel lidah buaya yang disimpan pada suhu ruang bertahan hingga hari ke 9, sedangkan pada penyimpanan suhu rendah $10^{\circ} \mathrm{C}$ bertahan hingga hari ke $21^{[8]}$.

Dari Tabel 3 menunjukkan bahwa penambahan pengawet Sodium Benzoat memberikan hasil yang lebih baik dibandingkan dengan pengawet Potassium Sorbat berdasarkan penampakan warna gel lidah buaya. Penampakan fisik gel lidah buaya dengan penambahan pengawet Sodium Benzoat menunjukkan warna gel nya masih kuning muda saat disimpan di kulkas selama 14 hari, belum berubah warna menjadi merah dan coklat muda seperti pada gel yang ditambahkan pengawet Potassium Sorbat. Penampakan fisik gel lidah buaya yang telah ditambah pengawet dengan berbagai perlakuan dapat dilihat pada Gambar 1.

Sebagai perbandingan, pada hasil penelitian terdahulu menyebutkan Squash yang ditambah sodium benzoat, potassium sorbat dan kombinasi sodium sorbatpotasium sorbat mempunyai umur simpan yang lebih panjang dibanding Squash kontrol. Squash kersen kontrol rusak pada hari keempat sedangkan squash yang ditambah sodium benzoat (400 ppm) dan squash yang ditambah potasium sorbat (400 ppm) rusak pada hari ke 12 ${ }^{[9]}$. Jadi Sodium Benzoat memang efektif digunakan sebagai pengawet. Mekanisme kerja benzoat dan garamnya berdasarkan permeabilitas dari membran sel mikroba terhadap molekul asam yang tidak terdisosiasi. Isi sel mikroba mempunyai $\mathrm{pH}$ yang selalu netral. Bila sel mikroba menjadi asam/basa maka akan terjadi gangguan pada organ-organ sel sehingga metabolisme terhambat dan akhirnya sebagian sel mati ${ }^{[10]}$.
Tabel 2. Hasil pengamatan warna gel lidah buaya dengan perlakuan pada suhu kamar dan perlakuan dimasukkan ke dalam kulkas

\begin{tabular}{ccccc}
\hline & & & \multicolumn{2}{c}{ Warna Gel Pada Hari Ke- } \\
\cline { 3 - 5 } No. & \multirow{2}{*}{ Perlakuan } & Hasil Awal & Pada & Dimasukkan \\
& & & $\begin{array}{c}\text { suhu } \\
\text { kamar }\end{array}$ & ke dalam \\
& & & kulkas \\
\hline 1. & $\mathrm{P}_{0,05}$ & Putih & Merah & Kuning \\
& & kekuningan & tua & \\
\hline 2. & $\mathrm{P}_{0,1}$ & Putih & Merah & Kuning \\
& & kekuningan & tua & \\
\hline 3. & $\mathrm{P}_{0,15}$ & Putih & Merah & Kuning keruh \\
& & kekuningan & tua & \\
\hline
\end{tabular}

Keterangan Tabel :

$\mathrm{P}_{0,05}$ : Gel lidah buaya ditambah pengawet Potassium Sorbat konsentrasi 0,05\% $\mathrm{P}_{0,05}$ : Gel lidah buaya ditambah pengawet Potassium Sorbat konsentrasi $0,10 \%$ $\mathrm{P}_{0,15}$ : Gel lidah buaya ditambah pengawet Potassium Sorbat konsentrasi $0,15 \%$

Tabel 3. Hasil pengamatan warna gel lidah buaya dengan perlakuan penambahan pengawet Potassium Sorbat dan Sodium Benzoat, dimasukkan ke dalam kulkas

\begin{tabular}{cccc}
\hline No. & Perlakuan & Hasil Awal & $\begin{array}{c}\text { Warna Gel Pada Hari } \\
\text { Ke-14 }\end{array}$ \\
\hline 1. & $\mathrm{P}_{0,05}$ & $\begin{array}{c}\text { putih } \\
\text { kekuningan }\end{array}$ & Coklat muda \\
\hline 2. & $\mathrm{P}_{0,1}$ & $\begin{array}{c}\text { putih } \\
\text { kekuningan }\end{array}$ & Merah muda \\
\hline 3. & $\mathrm{P}_{0,15}$ & $\begin{array}{c}\text { putih } \\
\text { kekuningan }\end{array}$ & Merah muda \\
\hline 4. & $\mathrm{~S}_{0,05}$ & $\begin{array}{c}\text { putih } \\
\text { kekuningan }\end{array}$ & Kuning muda \\
\hline 5. & $\mathrm{~S}_{0,1}$ & $\begin{array}{c}\text { putih } \\
\text { kekuningan } \\
\text { putih } \\
\text { kekuningan }\end{array}$ & Kuning muda \\
\hline 6. & $\mathrm{~S}_{0,15}$ & Kuning muda \\
\hline
\end{tabular}

Keterangan Tabel :

$\mathrm{P}_{0,05}$ : Gel lidah buaya ditambah pengawet Potassium Sorbat konsentrasi 0,05\% $\mathrm{P}_{0,10}$ : Gel lidah buaya ditambah pengawet Potassium Sorbat konsentrasi 0,10\% $\mathrm{P}_{0,15}$ : Gel lidah buaya ditambah pengawet Potassium Sorbat konsentrasi $0,15 \%$ $\mathrm{S}_{0,05}$ : Gel lidah buaya ditambah pengawet Sodium Benzoat konsentrasi 0,05\% $\mathrm{S}_{0,10}$ : Gel lidah buaya ditambah pengawet Sodium Benzoat konsentrasi $0,10 \%$ $\mathrm{S}_{0,15}$ : Gel lidah buaya ditambah pengawet Sodium Benzoat konsentrasi 0,15\% 


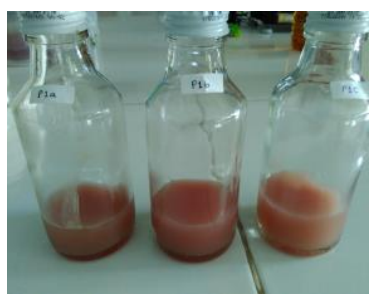

(a)

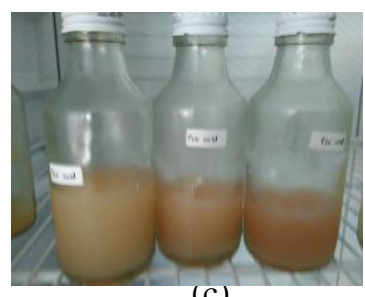

(c)

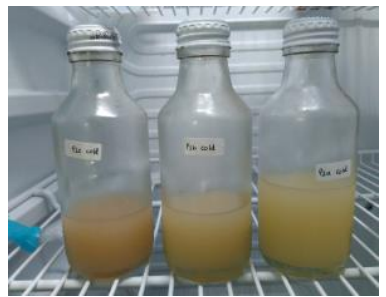

(b)

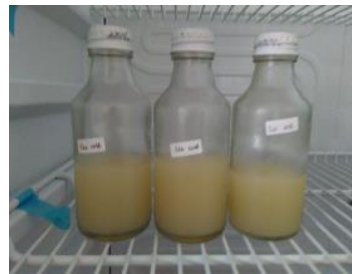

(d)
Gambar 1. Gel Lidah Buaya yang ditambah pengawet, (a): Gel Lidah Buaya yang ditambah Potassium Sorbat dan disimpan pada suhu kamar selama 7 hari; (b): Gel Lidah Buaya yang ditambah Potassium Sorbat dan disimpan dalam kulkas selama 7 hari; (c): Gel Lidah Buaya yang ditambah Potassium Sorbat dan disimpan dalam kulkas selama 14 hari; (d): Gel Lidah Buaya yang ditambah Sodium Benzoat dan disimpan dalam kulkas selama 14 hari.

\section{B. $\quad$ Angka Lempeng Total (ALT) Sediaan Gel Lidah Buaya}

Angka lempeng total merupakan salah satu metode perhitungan jumlah koloni mikroba baik bakteri maupun jamur yang terdapat pada sampel uji ${ }^{[11]}$. Hasil uji Angka Lempeng Total sediaan gel lidah buaya yang diperoleh dapat dilihat pada Tabel 4.

Tabel 4. Hasil uji Angka Lempeng Total (ALT) sediaan gel lidah buaya yang diperoleh dengan penambahan pengawet

\begin{tabular}{ccc}
\hline No. & Perlakuan & ALT $(\mathrm{kol} / \mathrm{gr})$ \\
\hline 1. & $\mathrm{P}_{0,05}$ & $1,5 \times 10^{3}$ \\
\hline 2. & $\mathrm{P}_{0,1}$ & $4,7 \times 10^{2}$ \\
\hline 3. & $\mathrm{P}_{0,15}$ & $1,3 \times 10^{3}$ \\
\hline 4. & $\mathrm{~S}_{0,05}$ & $3,9 \times 10^{3}$ \\
\hline 5. & $\mathrm{~S}_{0,1}$ & $<25$ \\
\hline 6. & $\mathrm{~S}_{0,15}$ & $6,5 \times 10^{5}$
\end{tabular}

\section{Keterangan Tabel :}

$\mathrm{P}_{0,05}$ : Gel lidah buaya ditambah pengawet Potassium Sorbat konsentrasi $0,05 \%$ $\mathrm{P}_{0,10}$ : Gel lidah buaya ditambah pengawet Potassium Sorbat konsentrasi $0,10 \%$ $\mathrm{P}_{0,15}$ : Gel lidah buaya ditambah pengawet Potassium Sorbat konsentrasi $0,15 \%$ $\mathrm{S}_{0,05}$ : Gel lidah buaya ditambah pengawet Sodium Benzoat konsentrasi 0,05\% $\mathrm{S}_{0,10}$ : Gel lidah buaya ditambah pengawet Sodium Benzoat konsentrasi $0,10 \%$ $\mathrm{S}_{0,15}$ : Gel lidah buaya ditambah pengawet Sodium Benzoat konsentrasi $0,15 \%$

Dari Tabel 4, dapat dilihat hasil uji ALT terbaik adalah pada variabel $S_{0,1}$ yakni pada gel lidah buaya yang ditambah pengawet Sodium Benzoat konsentrasi 0,10\% dengan hasil uji ALT sebesar < 25 koloni/gram.

Hal ini sesuai dengan penelitian terdahulu dimana digunakan sodium benzoat sebagai bahan pengawet untuk menghambat pertumbuhan bakteri pada gel lidah buaya sebanyak $0,1 \%{ }^{[2]}$.

Efektivitas bahan pengawet tergantung pada konsentrasi dan jenis bahan pengawet, jenis mikroba yang terdapat dalam bahan makanan. Bahan pengawet kimia dapat mengganggu pertumbuhan mikroba dengan cara mengganggu permeabilitas sel, mengganggu kerja enzim dan mengganggu sistem genetik ${ }^{[12]}$.

\section{Uji Aktivitas Antibakteri Escherichia coli}

Escherichia coli merupakan salah satu bakteri penyebab infeksi dalam saluran pencernaan. Pada beberapa kasus, Escherichia coli adalah bakteri yang paling banyak menimbulkan infeksi saluran cerna ${ }^{[13]}$.

Hasil uji aktivitas antibakteri Escherichia coli pada jus dan gel lidah buaya dapat dilihat pada Tabel 5. Hasil uji aktivitas antibakteri dengan metode kertas cakram dapat dilihat pada Gambar 2.

\begin{tabular}{cccc}
\multicolumn{3}{c}{ Tabel 5. Hasil uji aktivitas antibakteri Escherichia coli } \\
\hline No. & Perlakuan & \multicolumn{2}{c}{ Diameter Zona Hambat } \\
\cline { 3 - 4 } & & Jus Lidah Buaya & $\begin{array}{c}\text { Gel Lidah } \\
\text { Buaya }\end{array}$ \\
\hline 1. & Cakram 1 & $0,8 \mathrm{~cm}$ & $0,7 \mathrm{~cm}$ \\
\hline 2. & Cakram 2 & $0,9 \mathrm{~cm}$ & $0,5 \mathrm{~cm}$ \\
\hline & Rata-rata & $0,85 \mathrm{~cm}$ & $0,6 \mathrm{~cm}$ \\
\hline
\end{tabular}

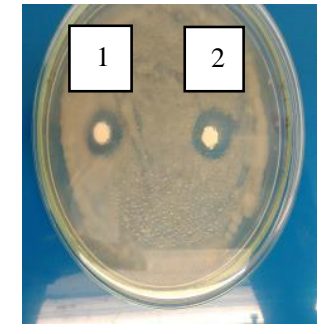

(a)

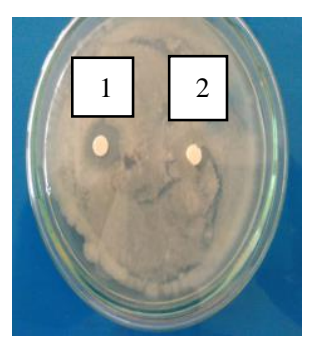

(b)
Gambar 2. Hasil Uji Aktifitas Antibakteri Escherichia coli dengan metode kertas cakram, (a): sampel jus lidah buaya; (b): sampel gel lidah buaya

Hasil uji menunjukkan bahwa jus lidah buaya dan gel lidah buaya memiliki aktivitas antibakteri Escherichia coli kriteria sedang dengan diameter zona hambat untuk jus lidah buaya rata rata sebesar $0,85 \mathrm{~cm}$ dan diameter zona hambat untuk gel lidah buaya rata-rata sebesar $0,6 \mathrm{~cm}$. Hasil penelitian terdahulu menyebutkan bahwa ekstrak etanol daun lidah buaya (Aloe vera) memiliki aktivitas antibakteri dan antijamur terhadap bakteri Staphylococcus aureus dan jamur Candida albicans yang ditandai dengan adanya zona bening. Pada bakteri Staphylococcus aureus memberikan zona hambat optimum pada konsentrasi 4,5\% dengan diameter 10,8 mm sedangkan pada, jamur Candida albicans memberikan zona 
hambat optimum pada konsentrasi $12 \%$ dengan diameter hambatan $18,87 \mathrm{~mm}^{[14]}$.

Hal tersebut di atas menunjukkan bahwa lidah buaya memang efektif sebagai bahan antibakteri. Gel lidah buaya merupakan material jernih, semi solid, dan tidak memiliki rasa yang mengandung $96 \%$ air dan $4 \%$ padatan. Daun lidah buaya mempunyai kandungan zat gizi seperti vitamin, mineral, enzim, asam amino ${ }^{[15]}$. Kandungan gel daun lidah buaya yang berperan sebagai antibakteri diantaranya polisakarida (glukomannan dan acemannan), senyawa saponin, sterol, fenol dan tanin. Kesinergisan aktifitas dari seluruh zat aktif inilah yang berkontibusi terhadap khasiat daun lidah buaya ${ }^{[16]}$. Beberapa bukti sejarah menyebutkan bangsa Arab, Yunani, Romawi, India dan Cina telah menggunakan sebagai bahan obat aneka penyakit karena sifatnya sebagai anti inflamasi, anti jamur, anti bakteri dan proses regenerasi sel ${ }^{[15]}$.

\section{KESIMPULAN}

Gel lidah buaya yang telah ditambahkan pengawet Sodium Benzoat sebesar 0,10\% memberikan hasil terbaik dalam lama penyimpanan yakni dengan masa simpan 14 hari di dalam kulkas, warna gel kuning muda dan memiliki hasil uji Angka Lempeng Total (ALT) terbaik yakni < 25 koloni/ gram. Jus dan gel lidah buaya memiliki daya hambat terhadap bakteri Escherichia coli, ditunjukkan dengan diameter zona hambat jus dan gel lidah buaya masing-masing rata-rata sebesar 0,85 dan $0,6 \mathrm{~cm}$.

\section{UCAPAN TERIMA KASIH}

Penulis mengucapkan terima kasih kepada Kepala Baristand Industri Pontianak dan Kepala Seksi Teknologi Industri Baristand Industri Pontianak, rekan-rekan tim peneliti, dewan redaksi majalah dan semua pihak yang telah membantu sehingga penelitian ini dapat terlaksana dan tulisan ini dapat diterbitkan.

\section{DAFTAR PUSTAKA}

[1] Fadhilah, Syahida Rizki. 2008. Analisis Sikap Konsumen Terhadap Minuman Lidah Buaya (Aloe vera) Kavera. Fakultas Pertanian. Institut Pertanian Bogor. Bogor.

[2] Suryani, Ani, Erliza Hambali dan Hasanah Kurniadewi. 2005. Kajian Penggunaan Lidah Buaya (Aloe vera) Dan Bee Pollen Pada Pembuatan
Sabun Opaque. Jurnal Teknologi Industri Pertanian. Volume 15 (2), Hal. 40-45.

[3] Widiastuti, D. dan M. Hatta. 2002. Pemanfaatan Lahan Gambut untuk Budidaya Pertanian di Kalimantan Barat. Pontianak: BPTP Kalimantan Barat.

[4] Hidayat, Rahmad. 2012. Maksimalisasi Pendapatan Usahatani Lidah Buaya (Aloe vera) Di Kecamatan Pontianak Utara. Jurnal Iprekas-Ilmu Pengetahuan dan Rekayasa. Edisi Januari 2012: 18-26

[5] Furnawanthi, I. 2002. Khasiat dan Manfaat Lidah Buaya. Jakarta:Agro Media Pustaka

[6] Sulaeman, S. 2008. Model Pengembangan Agribisnis Komoditi Lidah Buaya (Aloe vera). Deputi Bidang Penelitian dan Pengkajian Sumberdaya UKMK.

[7] Davis. Stout. 1971. Disc Plate Method of Microbiological Antibiotic Essay. Journal of Microbiology. Volume 22 Nomor 4: 659-665.

[8] Marwina, Rina, Raida Agustina dan Bambang Sukarno Putra. 2016. Perubahan Mutu Tomat (Lycopersicon esculentum Mill) Dengan Variasi Konsentrasi Pelapisan Gel Lidah Buaya (Aloe vera L.) Dan Suhu Penyimpanan. Jurnal Ilmiah Mahasiswa Pertanian Unsyiah. Volume 1. Nomor 1. November 2016: 985-994.

[9] Niken, Exsuparantia. 2012. Pengaruh Sodium Benzoat, Potasium Sorbat dan Kombinasi Sodium Benzoat-Potasium Sorbat Terhadap Kualitas dan Umur Simpan Squash Kersen (Muntigia colabura L.). Skripsi. Fakultas Teknologi Pertanian. Universitas Katolik Soegijapranata Semarang.

[10] Khurniyati, M. Ilhami dan Teti Estiasih. 2015. Pengaruh Konsentrasi Natrium Benzoat dan Kondisi Pesteurisasi (Suhu dan Waktu) Terhadap Karakteristik Minuman Sari Apel Berbagai Varietas: Kajian Pustaka. Jurnal Pangan dan Agroindustri, Volume 3 Nomor 2: 523-529

[11] Rijal, Muhammad. 2016. Analisis Kandungan MPN dan ALT Total Pada Fish Nugget Berbahan Dasar Limbah Ikan. Jurnal Biologi Science and Education. Volume 5. Nomor 2. Halaman 57-65.

[12] Zentimer, S. 2007. Pengaruh Konsentrasi Natrium Benzoat dan Lama Penyimpanan Terhadap Mutu Minuman Sari Buah Sirsak (Annona muricata) Berkarbonasi. Departemen Teknologi Pertanian. Fakultas Pertanian. Universitas Sumatera Utara

[13] Rahmawati, Nurina, Edhy Sudjarwo dan Eko Widodo. 2014. Uji Aktivitas Antibakteri Ekstrak Herbal Terhadap Bakteri Escherichia coli. Jurnal Ilmu-Ilmu Peternakan. 24(3): 24-31.

[14] Sulistyowati, Ike. 2012. Uji Aktivitas Ekstrak Etanol Daun Lidah Buaya (Aloe vera) Terhadap Bakteri Staphylococcus aureus Dan Jamur Candida albicans. Skripsi. Universitas Islam Negeri Alauddin Makassar.

[15] Arifin, J. 2015. Intensif Budidaya Lidah Buaya. Yogyakarta: Pustaka Baru Press

[16] Iriano Armalia. 2008. Efek Antibakteri Infusum Aloe vera Terhadap Porphyromonas gingivalis In vitro. Skripsi. Jakarta : FKG Universitas Indonesia. 